\title{
COMPARISON OF THE SUPPORT FOR CATCH CROPS IN THE BALTIC SEA REGION COUNTRIES
}

\author{
Agnese Krieviņa, Ieva Leimane \\ Institute of Agricultural Resources and Economics, Latvia \\ agnese.krievina@arei.lv
}

\begin{abstract}
Catch crops contribute to soil and environmental quality, which has determined a growing interest in their use as a nature-based solution. Though, the introduction of catch crops increases the complexity of farm management and is related with additional costs. In Latvia, the area under catch crops accounts for less than $5 \%$ of the arable land, while $30 \%$ is bare over the winter. In order to identify the possibilities for promoting of catch crops in Latvia, the objective of the study is to explore the support practices for growing of catch crops in the Baltic Sea region countries. The paper seeks to explore the main benefits associated with the growing of catch crops, followed by the study and synthesis of the main support measures. For the study, numerous information sources have been explored and appropriate research methods applied. Catch crops reduce nutrient leaching from the soil, transfer nutrients to the next crop, improve soil quality, reduce soil erosion, and mitigate climate change; these benefits can translate also at farm level, mainly as reduced $\mathrm{N}$ inputs. Growing of catch crops is being increasingly supported in the Baltic Sea countries as a greening measure and by different agri-environment and climate measures of the RDPs 2014-2020. Growing of economic focus area catch crops (supported in quite a similar approach in these countries) and introduction of agri-environment scheme for catch crops (supported in directly and/or indirectly targeted way) can contribute to the solving of environmental problems and decrease the share of bare land left over the winter in Latvia.
\end{abstract}

Key words: catch crops, support, ecologic focus area, the Baltic Sea region countries.

\section{Introduction}

Catch crops are grown as supplementary crops after harvesting of the main crop with the primary purpose of capturing excess $\mathrm{N}$ released from the remains of the harvested crop or the soil and thus preventing leaching losses (Cicek et al., 2015; Guo et al., 2018; Molinuevo-Salces et al., 2013). They also ensure soil protection by providing plant cover after the harvest of the main crop. The term 'catch crops' is very often used interchangeably with the term 'cover crops'. In the context of the EU statistics and land use modelling, cover crops are defined as the crops that are not normal winter crops or grassland but are sown specifically to protect bare soil in winter or other periods when it would otherwise be bare and susceptible to losses. The economic interest of these crops is low, and the main goal is soil and nutrient protection (Eurostat, 2013b; Panagos et al., 2015). Catch crops may be undersown at the same time when the main crop (i.e., under-sowings), or catch crops may be grown between the two main crops and sown after the harvest of the main crop (i.e., intercrops).

Due to the significant contribution to the soil conservation and environmental quality, there has been a growing interest in considering catch crops as a nature-based solutions (NBS) practice globally, indicated, e.g., by doubling catch crop area in the United States of America (Daryantoa et al., 2018). Also, in Europe, the interest in catch crops has been expanding by the introduction of the greening component to the direct payment system in 2015 . Overall, the growing of catch crops has been widely applied land management practice in temperate climates of Europe (De Baets et al., 2011), though, the introduction of these crops can add to the complexity of farming (Daryantoa et al., 2018). Therefore, the number of catch crop growers is still limited due to the challenges associated with adoption of the practice, particularly for smallholders, which include the lack of knowledge and skills, access to cover crop seeds, training and technical assistance (Daryantoa et al., 2018).

In Latvia, the area under catch crops accounts for less than $5 \%$ of the arable land, while $30 \%$ of the land is left bare over the winter (CSB, 2018), which along other Baltic States is the largest indicator in the Baltic Sea region countries (Eurostat, 2013a). However, according to the environmental objectives of the future CAP, soil protection and quality conditions will require that there is no bare soil in most sensitive periods (EC, 2019). Growing of catch crops is related with additional costs for farmers, but up to now there has been a limited experience regarding the introduction of relevant and efficient catch crop solutions into farmland management practices, including related support measures in Latvia.

In order to identify the possibilities for promoting of catch crops in Latvia, the objective of the study is to explore the support practices for growing of catch crops in the Baltic Sea region countries. The paper first seeks to explore the main benefits associated with the growing of catch crops, followed by the study and synthesis of the main support measures for catch crops provided by the greening requirements of direct payment system and agri-environment and climate actions of national rural development programmes (RDPs) for 2014-2020 in the Baltic Sea region countries. 
In the study, the Baltic Sea region countries refer to the European Union (EU) countries having a shoreline along the Baltic Sea - Latvia, Lithuania, Estonia, Poland, Finland, Denmark and Germany.

\section{Materials and Methods}

The main data sources for the study are the national RDPs 2014-2020 of the analysed Baltic Sea region countries (Bavaria is chosen for Germany) prepared by the relevant ministries, complemented by the detailed information on the support requirements available from the national agricultural support paying agencies (websites) in each of the countries. Different publications and papers, e.g., research papers and the reports of institutions have also been applied in the study.

For various solutions in the process of the study appropriate qualitative and quantitative research methods have been used: monographic, analysis and synthesis, data grouping, logical and abstractive constructional, etc.

\section{Results and Discussion}

The main benefits of the growing of catch crops

The main benefits associated with the growing of catch crops is the reduction of nutrient leaching from the soil, transfer of nutrients to the next crop, improving of soil quality, reduction of soil erosion by water, as well as mitigation of climate change, which can translate also as a farm level benefits, mainly as reduced $\mathrm{N}$ inputs and the possibility to reduce the costs of mineral fertilisers.

Intensive agriculture and bare soils increase the risk of $\mathrm{N}$ leaching to groundwaters, causing water pollution and eutrophication of water bodies, with negative impacts to human health and the environment. Generally, the leaching occurs due to the oversupply of $\mathrm{N}$ from the soil and fertilisers exceeding the needs of agricultural crops. The period of a particular risk of leaching is late-autumn and winter, when residual $\mathrm{N}$ from the harvest of spring crops is exposed to leaching due to more frequent drainage events. Catch crops grown during the autumn-winter period between two main crops in annual rotation are considered an effective solution to decrease $\mathrm{N}$ leaching due to their ability to capture soil mineral N (Couëdel et al., 2018, Teixeira et al., 2016). Furthermore, catch crops have been shown to be more effective in capturing excess $\mathrm{N}$ than such management practices as reduced tillage and reduced fertiliser inputs (Cicek et al., 2015; Valkama et al., 2015). To maximize $\mathrm{N}$ uptake, early establishment of catch crops is generally recommended (Teixeira et al., 2016). Under-sowings enable an immediate uptake of residual $\mathrm{N}$ after the harvest of the main crop, and they are considered particularly potential in the countries with a short growing season, where the time after the main crops is too short for post-harvest catch crops (Peltonen-Sainio et al., 2015; Valkama et al., 2015).

After the end of the vegetation, nutrients that have been up-taken and retained in catch crops can be transferred to the following crop, upon catch crop biomass incorporation into the soil (Couëdela et al., 2018; Piotrowska-Dlugosz \& Wilczewski, 2015; Tosti et al., 2014). Late catch crop termination is usually recommended as this allows higher $\mathrm{N}$ accumulation in the biomass and also provides better synchronization of the released $\mathrm{N}$ from the decomposing catch crop residues with $\mathrm{N}$ uptake by the next crop (Daryantoa et al., 2018). Catch crop residue decomposition and subsequent $\mathrm{N}$ mineralization depends primarily on soil temperature, water content, biochemical constituents, residue quantity and inversely proportional to the $\mathrm{C}: \mathrm{N}$ ratio. (Couëdela et al., 2018; Piotrowska-Dlugosz \& Wilczewski, 2015; Tosti et al., 2014). Catch crop use as a green manure is considered to be an important management practice with the potential to reduce the dependence on mineral fertilisers (PiotrowskaDlugosz \& Wilczewski, 2015).

Along with nutrients retention, catch crops have been recognized as a favourable practice for the accretion of soil organic matter (SOM) (PiotrowskaDlugosz \& Wilczewski, 2015). SOM is a major nutrient source for plant growth, it also affects the activities of soil microorganisms and improves soil structure (better aeration, moisture retention, buffering and exchange capacity) (Function of organic...). The growing of catch crops increases $\mathrm{C}$ inputs into the soil, thus increasing soil organic carbon (SOC) (PiotrowskaDlugosz \& Wilczewski, 2015; Poeplau \& Don, 2015). Catch crops have a positive impact on maintaining or improving soil structure (Peltonen-Sainio et al., 2015), they improve soil physical, biological and chemical properties (Cerdà et al., 2018). Catch crops can also provide agronomic services including certain soil microorganism induction, rarer incidence of certain soil pathogens and early-season weeds (Daryantoa et al., 2018).

Catch crops improve soil quality also by reducing soil erosion (Molinuevo-Salces et al., 2013). As most of SOM is in the topsoil, with soil erosion, SOM is lost with it (Funderburg, 2016). Thus, soil erosion not only affects soil fertility and the resulting crop productivity, but it also contributes to the pollution of water bodies (Ritter, 2018). The use of catch crops for erosion control is related to their capacity to act as a buffer in reducing water-induced soil erosion by rainfall, to increase water infiltration rate resulting in less runoff volume, to reduce the flow rate of runoff across the soil surface, and binding of soil particles with plant roots (De Baets et al., 2011; Kaspar, 2009). To be effective, catch crops must be quick to establish, provide an early plant cover, be aggressive enough to 
suppress weeds and have a deep root system (Morgan, 2005). Catch crops can be a very effective erosion control and environmental conservation technique (De Baets et al., 2011).

Growing of catch crops is an important management option to increase SOC stocks in agricultural soils thus mitigating climate change. It has been found that catch crop potential is the same as for other organicinput-related $\mathrm{C}$ sequestration management options in agricultural soils and almost as effective as landuse changes like afforestation of croplands (Poeplau $\&$ Don, 2015). Considering that catch crops reduce $\mathrm{N}$ leaching, they have a potential to contribute to the reduction of indirect $\mathrm{N}_{2} \mathrm{O}$ emissions. Though there is not a consensus regarding the effect of catch crops on direct $\mathrm{N}_{2} \mathrm{O}$ emissions as they do not always reduce direct $\mathrm{N}_{2} \mathrm{O}$ emissions from the soil surface in the short term. In general, catch crops have seemingly a greater potential to reduce $\mathrm{N}_{2} \mathrm{O}$ emissions when nonlegume species are grown and their residue is not incorporated into the soil. Even a small reduction in $\mathrm{N}_{2} \mathrm{O}$ emissions from agricultural soils can have a large impact on global warming because $\mathrm{N}_{2} \mathrm{O}$ is about 300 times more potent than $\mathrm{CO}_{2}$ (Basche et al., 2014).

Along the potential benefits of catch crops to farmers, the introduction of catch crops, as it has been mentioned before, can also make farm management more complex. Some other disadvantaged mentioned for catch crops include reducing water availability, especially in dry periods, as well as competition with the main crops for nutrients in the case of under-sowings (Valkama et al., 2015; Daryantoa et al., 2018).

The support for catch crops in the Baltic Sea region countries

Due to the associated environmental benefits, the growing of catch crops is being increasingly supported in farmer support schemes in the EU countries - mainly as a greening measure and by different agri-environment and climate measures of the RDPs 2014-2020. The first refers to the mandatory greening requirements introduced in 2015 regarding the preservation of permanent grassland, crop diversification and having ecological focus area (EFA), the observation of which allows receiving direct payments - basic payment alongside greening payment. The general rule is that farms with more than 15 ha of arable land ensure that at least $5 \%$ of their arable land is EFA. The area under catch crops or green cover was one of the available options countries could choose to be considered as EFA, and one ha of catch crops is counted as 0.3 ha of EFA (Regulation 1307/2013). While greening is a compulsory requirement set by the CAP, agri-environment measures go beyond mandatory standards and provide additional environmental benefit (Sulima, 2016).
The possibilities to declare the area under catch crops as EFA in the Baltic Sea region countries is summarized in Table 1. For Germany the case of Bavaria has been studied as it is the state with the largest arable land area.

Catch crops are not defined as one of the categories eligible for fulfilling of the EFA requirement only in Estonia and Finland. In other Baltic Sea region countries both under-sowings and intercrops classify for the EFA. Overall, under-sowings should consist of grasses and/or legumes, while intercrops should be a mixture of at least two crops. The most flexibility for intercrop species is provided in Poland as the eligible crops are defined quite broadly (cereals, oilseeds, fodder, legumes and melliferous plants), followed by Denmark (in general case).

Considering the dates by which EFA intercrops should be sown and dates until which they cannot be destroyed, generally they have to be maintained for about 60 days in the Baltic Sea countries, with the exception of Bavaria, where the mandatory period is almost 140 days, and Poland, if the option of winter intercrops is chosen. In Denmark, intercrops should be maintained for about 80 days, only for some crops the period is 60 days.

Generally, there is a requirement that EFA intercrops should be followed by a different main crop than the catch crop. It is forbidden to apply plant protection products during the period of the maintenance of intercrops. In Bavaria, catch crops can be used as a pasture for sheep or goats. Also, in Denmark defined uses of EFA catch crops are allowed if an appropriate green mass of catch crops can be ensured. To avoid double financing, it is not possible to declare the same area of catch crops for agri-environmental support and as EFA at the same time.

The available data of 2016 in Figure 1 indicate that the area under catch crops accounts for $30 \%$ of the total area declared as EFA in the EU-28. In Denmark, almost all EFA is comprised of catch crops and green cover, followed by Germany and Poland. At the EU-28 level, more popular option than catch crops has been only nitrogen fixing crops (47\%). These two choices both can be considered as more productive options, which could largely explain their popularity. When explaining the preference towards catch crops of German farmers, the easy implementation, possibility to integrate in crop-rotation, continuing cultivation of the land, established management practices, erosion protection, maintenance of soil fertility, land cover as a shelter for wild animals were identified, with disincentives being reducing water availability and challenge to determine possible crop combination (Zinngrebe et al., 2017). In Denmark, the fact of established management practices arising from the mandatory catch crop growing requirement and the 
Catch crops as EFA in the Baltic Sea region countries (based on requirements for 2018)

\begin{tabular}{|c|c|c|c|c|}
\hline Country & Types & Variety of species & Sowing date & Termination date \\
\hline Latvia & $\begin{array}{l}\text { under- } \\
\text { sowings, } \\
\text { intercrops }\end{array}$ & $\begin{array}{l}\text { under-sowing of grasses } \\
\text { and legumes; mixture of a } \\
\text { minimum of } 2 \text { intercrops }{ }^{1}\end{array}$ & by September 1 (intercrops) & after October 31 (intercrops) \\
\hline Lithuania & $\begin{array}{l}\text { under- } \\
\text { sowings, } \\
\text { intercrops }\end{array}$ & $\begin{array}{l}\text { under-sowing of grasses } \\
\text { or legumes; mixtures of a } \\
\text { minimum of } 2 \text { intercrops }{ }^{2}\end{array}$ & $\begin{array}{l}\text { from April } 1 \text { to June } 30 \\
\text { (under-sowings); from June } \\
30 \text { to August } 15 \text { (intercrops) } \\
\end{array}$ & $\begin{array}{l}\text { after October } 15 \text { (or until sowing of } \\
\text { winter crops (under-sowings); or } 8 \\
\text { weeks after sowing of a mixture) }\end{array}$ \\
\hline Estonia & - & - & - & - \\
\hline Poland & $\begin{array}{l}\text { under- } \\
\text { sowings, } \\
\text { intercrops }\end{array}$ & $\begin{array}{l}\text { under-sowing of grasses or } \\
\text { small-seed legumes; mixtures } \\
\text { of at least } 2 \text { intercrops }{ }^{3}\end{array}$ & $\begin{array}{l}\text { from July } 1 \text { to August } 20 \\
\text { (stubble intercrops); } \\
\text { from July } 1 \text { to October } 1 \\
\text { (winter intercrops) }\end{array}$ & $\begin{array}{l}\text { after October } 15 \text { (or } 8 \text { weeks after } \\
\text { sowing of a mixture) (stubble } \\
\text { intercrops); after February } 15 \\
\text { (winter intercrops) }\end{array}$ \\
\hline Finland & - & - & - & - \\
\hline Sweden & $\begin{array}{l}\text { under- } \\
\text { sowings, } \\
\text { intercrops }\end{array}$ & $\begin{array}{l}\text { under-sowing of grasses and/ } \\
\text { or legumes; mixture of at least } \\
2 \text { intercrops }\end{array}$ & $\begin{array}{l}\text { before September } 1 \\
\text { (intercrops) }\end{array}$ & from November 1 \\
\hline Denmark & $\begin{array}{l}\text { under- } \\
\text { sowings, } \\
\text { intercrops }\end{array}$ & $\begin{array}{l}\text { under-sowing of grasses and/ } \\
\text { or legumes; mixture of at least } \\
2 \text { intercrops }\end{array}$ & $\begin{array}{l}\text { by June } 30 \text { (under-sowings); } \\
\text { from June } 30 \text { to August } 1 \text { or } \\
\text { August } 20 \text { (intercrops) }\end{array}$ & $\begin{array}{l}\text { from October } 20 \text { (or } 8 \text { weeks after } \\
\text { the harvesting of maize (under- } \\
\text { sowings)) }\end{array}$ \\
\hline $\begin{array}{l}\text { Germany } \\
\text { (Bavaria) }\end{array}$ & $\begin{array}{l}\text { under- } \\
\text { sowings, } \\
\text { intercrops }\end{array}$ & $\begin{array}{l}\text { under-sowing of grasses and/ } \\
\text { or legumes; mixture of at least } \\
2 \text { intercrops }(\max 60 \% \text { for } \\
\text { one crop; grasses } \max 60 \%)\end{array}$ & by October 1 (intercrops) & after January 15; after February 15 \\
\hline
\end{tabular}

${ }^{1}$ summer rape, Italian ryegrass, white mustard, oil radish, oats, phacelia, buckwheat, summer vetch, winter vetch, rye, beans, peas or fodder radish.

${ }^{2}$ listed in Regulation on direct payments (December 4, 2015 No. 3D-897).

${ }^{3}$ cereals, oilseeds, fodder, legumes and melliferous plants (mixtures cannot consist of cereals only).

${ }^{4}$ beet, red clover, buckwheat, oats (spring), phacelia, barley (spring), oil radish, Persian clover, bristle oat, ryegrass, rape (spring), turnip rape (spring), rye (spring), triticale (spring), radish, sunflower, subterranean clover, Sudan grass, tagetes, wheat (spring), vetch, white mustard, pea. The mixture must not contain any other than these crops.

${ }^{5}$ cereals, grasses, cruciferous plants, chicory and honeycomb (by August 1); spring barley, common rye, perennial rye, hybrid rye or oats, cruciferous plants, honeycomb (by August 20).

${ }^{6}$ listed in Appendix 3 of DirektZahlDurchfV (Regulation on the implementation of direct payments).

Source: based on the support requirements available from the national agricultural support paying agencies.

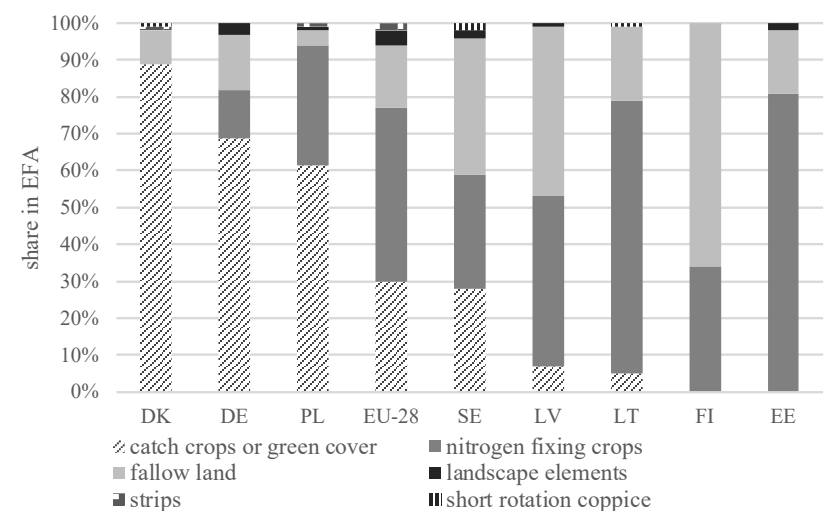

Figure 1. Composition of EFA in the Baltic Sea region countries in 2016.

Source: based on DG Agri (2018) data.

possibility to declare mandatory catch crops also for the EFA could be the main explaining factor for its high share. As the growing of catch crops is related to additional production costs, this could be one of the reasons for small popularity of catch crops in Latvia so far because farmers lack experience and confidence about the benefits that catch crops can provide at the farm level.

The overview of the support to catch crops under agri-environment and climate measures of the RDPs 
Catch crops within agri-environment measures of RDPs 2014-2020 in the Baltic Sea region countries

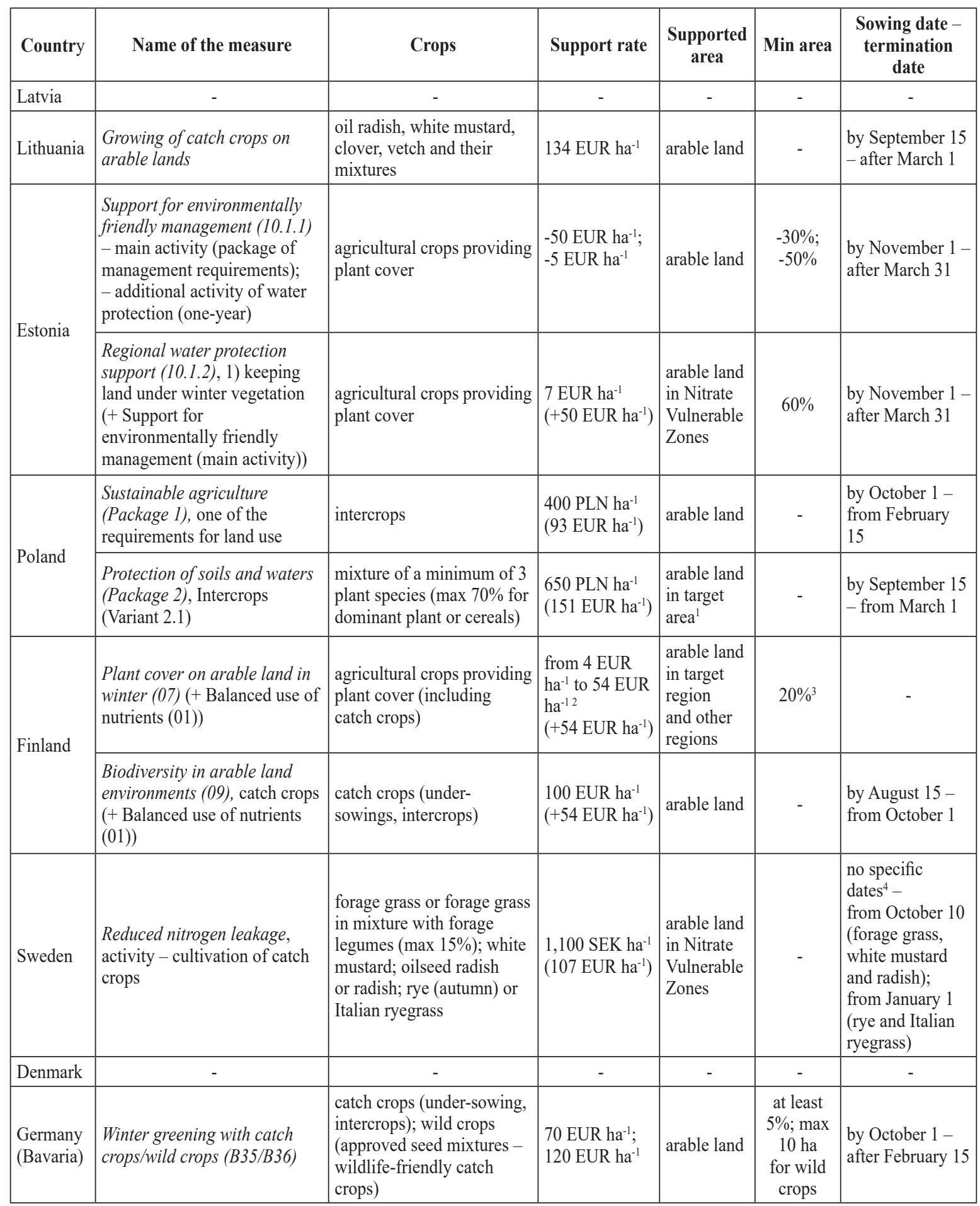

${ }^{1}$ areas particularly at risk of water erosion, problem areas with low humus content and areas particularly exposed to nitrates from agricultural sources.

${ }^{2} 4 \mathrm{EUR} \mathrm{ha}^{-1}$, if plant cover is $20 \%$; $18 \mathrm{EUR} \mathrm{ha}^{-1}$ in the target region and $9 \mathrm{EUR} \mathrm{ha}^{-1}$ in other regions, if plant cover is $40 \%$; $36 \mathrm{EUR} \mathrm{ha}^{-1}$ in the target region and $11 \mathrm{EUR} \mathrm{ha}^{-1}$ in other regions, if plant cover is $60 \% ; 54 \mathrm{EUR} \mathrm{ha}^{-1}$ in the target region, if plant cover is $80 \%$.

${ }^{3}$ may be implemented also by reduced tillage; in other areas, plant cover may be implemented in full with reduced tillage. ${ }^{4}$ catch crops should be able to develop well and pick up nitrogen after harvesting the main crop.

Source: based on the information from national RDPs 2014-2020 and the support requirements available from the national agricultural support paying agencies. 
2014-2020 in the Baltic Sea region countries is summarized in Table 2.

Latvia and Denmark are the countries with no agri-environment support provided for the growing of catch crops in their RDPs. At the same time, Danish farmers have experience of growing catch crops because catch crops have been a mandatory part of the implementation of the Nitrate Directive in Denmark since the late 1980-ties. Farms with an annual turnover over DKK 50,000 ( EUR 6,700) and a total area of 10 ha or more, should establish a minimum amount of catch crops $(10 \%$ or $14 \%$ of arable land for farms according to the amount of the use of livestock manure). If farmers do not comply with the requirement, fertiliser quota for the farm is reduced correspondingly. In addition to the common mandatory catch crops, there are two other schemes included in the latest Danish Nitrate Action Programme: a general catch crop scheme for holdings using organic manure, and targeted catch crop scheme which is designed as a de minimis aid scheme for voluntary establishment of additional catch crops in order to avoid an increase in $\mathrm{N}$ leaching, as in 2015 the Danish government cancelled the reduction of nitrogen application standards for farming' (EPA, 2018).

There is no directly targeted agri-environment support for catch crops in Estonia, though catch crops are supported as one of the environmentally friendly practices along other agricultural crops on arable land serving as a plant cover on at least $30 \%$ of eligible land under the measure 'Support for environmentally friendly management' (main activity). In addition, it is also possible to select a one-year 'Additional activity of water protection', which requires that at least $50 \%$ of eligible land is kept under winter vegetation. 'Regional water protection support' is a specific measure targeted at Nitrate Vulnerable Zones, when the land kept under winter vegetation makes at least $60 \%$.

A single targeted agri-environment measure for catch crops per country is available in Lithuania and Sweden. Agri-environment support measure 'Growing of catch crops on arable lands' has been introduced in Lithuania since 2018, and under the current support scheme only a limited number of postharvest catch crops can be grown (oil radish, white mustard, clover, vetch and their mixtures). Catch crops cannot be mowed, and the biomass of catch crops has to be incorporated in the land before the sowing of the main crop.

In Sweden, the measure 'Reduced nitrogen leakage' with its activity - cultivation of catch crops - is available for Nitrate Vulnerable Zones. A limited number and use of catch crops are allowed grasses should be grown as under-sowing in the main crops; white mustard, oil radish and radish can be grown as under-sowings and intercrops; rye and Italian ryegrass can be used as intercrops only after potatoes and vegetables.

In Poland and Finland, agri-environment support for catch crops is provided both in a directly targeted and indirect way. In Poland, there is one catch crop specific agri-environment measure, while another measure stimulates the growing of catch crop within a set of requirements for sustainable land management. Package 2 'Protection of soils and waters' of Agri-environmental-climate action (M10) targets the growing of catch crops by its Variant 2.1'Intercrops'. The support is provided in designated areas particularly at risk of water erosion (about $8.2 \%$ ), problem areas with low humus content (around $3.6 \%$ ) and areas particularly exposed to nitrates from agriculture $(7.4 \%)$. Intercrops should be used as a mixture of a minimum of 3 plant species, their biomass has to be incorporated in the land. Generally, package 1 'Sustainable agriculture' concerns the diversification of agricultural crops within sustainable land management. The requirements also provide that in one year the additional practice as growing of intercrops should be implemented, as well as growing of intercrops can be chosen from additional practices that should be implemented in another year.

In Finland, the growing of catch crops is targeted through agri-environment measure 'Biodiversity in arable land environments (09)', which is a parcelspecific operation. Catch crops may be grown as under-sowings or intercrops, plant species and plant varieties that are suitable for the area should be grown. At the same time, farmers have to apply for the measure 'Balanced use of nutrients (01)', a farmlevel operation that is a precondition for making a commitment on parcel-specific operations. There is another agri-environment support measure 'Plant cover on arable land in winter (07)', where growers of catch crops can benefit along other farmers providing plant cover in winter if the vegetation is maintained until the following spring. The parcel-specific operation is implemented in all parts of the country, but the requirements are more stringent in the target region (about $70 \%$ of arable land) for plant cover in winter.

In Bavaria, the measure 'Winter greening with catch crops/wild crops (B35/B36)' is targeted at catch crops. It covers catch crops grown as under-sowings and intercrops, and wild crops. The latter are specially approved seed mixtures - wildlife-friendly catch crops. The termination of catch crops may only be mechanical. Growers of catch crops can benefit also in some specific cases provided by some other agrienvironment measures.

Contrary to the EFA, catch crops under agrienvironment measures have to be maintained till the spring in all analysed countries, with the exception of 
Finland and Sweden, and it is generally common that the use of plant protection products and also fertilisers is prohibited on catch crops.

Different approaches are used at the national level for listing catch crops eligible for agri-environment support. In some countries (e.g, Lithuania, Sweden and Poland) the list of crops is rather closed, while in Finland the choice is left to farmers for picking the most suitable crops to the local conditions. This could depend on the objectives set in each country for the specific agri-environment measure. The more directly the support is targeted at catch crop benefits, the more precise list of supported crops and higher support rates are applied.

\section{Conclusions}

1. The possibility to fulfil the greening requirement of direct payments towards the EFA by catch crops is applied in most Baltic Sea region countries (except Estonia and Finland), with quite similar approach. The EFA fulfilment by catch crops can contribute to the decrease of the share of arable land that is left bare over the winter in Latvia.

2. The main benefits associated with catch crops is the reduction of nutrient leaching from the soil, transfer of nutrients to the next crop, improving of soil quality, reduction of soil erosion, as well as mitigation of climate change.

3. Considering the environmental benefits of catch crops, they are supported through public funds of RDPs allocated to agri-environment and climate actions in directly and/or indirectly targeted way in the Baltic Sea region countries. As Latvia has similar environmental problems, it could also introduce relevant agri-environment scheme for catch crops.

4. The benefits of catch crops can translate also at a farm level, mainly associated with lower $\mathrm{N}$ inputs and resulting in lower costs for mineral fertilisers.

5. The case of Denmark implies that there is a confidence about the environmental and farmlevel benefits of catch crops. To promote the understanding and confidence about the benefits of catch crops in Latvia, local field experiments are necessary.

\section{Acknowledgements}

The paper was supported by the Interreg LatvianLithuanian cross border cooperation project 'Catch Pollution'.

\section{References}

1. Basche, A.D., Miguez, F.E., Kaspar, T.C., \& Castellano, M.J. (2014). Do cover crops increase or decrease nitrous oxide emissions? A meta-analysis. Journal of Soil and Water Conservation, 69(6), 471-482. DOI: $10.2489 /$ jswc.69.6.471.

2. Central Statistical Bureau of Latvia (CSB). (2018). Soil cover in winter in agricultural holdings of various economic sizes. Retrieved February 2, 2019, from http://data1.csb.gov.lv/pxweb/en/lauks/?rxid=a39c3f49e95e-43e7-b4f0-dce111b48ba1.

3. Cerdà, A., Rodrigo-Comino, J., Giménez-Morera, A., \& Keesstra, S.D. (2018). Hydrological and erosional impact and farmer's perception on catch crops and weeds in citrus organic farming in Canyoles river watershed, Eastern Spain. Agriculture, Ecosystems \& Environment, 258, 49-58. DOI: 10.1016/j. agee.2018.02.015.

4. Cicek, H., Martens, J.R.T., Bamford, K.C., \& Entz, M.H. (2015). Late-season catch crops reduce nitrate leaching risk after grazed green manures but release $\mathrm{N}$ slower than wheat demand. Agriculture, ecosystems \& environment, 202, 31-41. DOI: 10.1016/j.agee.2014.12.007.

5. Couëdel, A., Alletto, L., Tribouillois, H., \& Justes, É. (2018). Cover crop crucifer-legume mixtures provide effective nitrate catch crop and nitrogen green manure ecosystem services. Agriculture, Ecosystems \& Environment, 254, 50-59. DOI: 10.1016/j.agee.2017.11.017.

6. Daryanto, S., Fu, B., Wang, L., Jacinthe, P.A., \& Zhao, W. (2018). Quantitative synthesis on the ecosystem services of cover crops. Earth-Science Reviews, 185, 357-373. DOI: 10.1016/j.earscirev.2018.06.013.

7. De Baets, S., Poesen, J., Meersmans, J., \& Serlet, L. (2011). Cover crops and their erosion-reducing effects during concentrated flow erosion. Catena, 85(3), 237-244. DOI: 10.1016/j.catena.2011.01.009.

8. DG Agri. (2018). CAP Indicators - Biodiversity. Retrieved February 5, 2019, from https://agridata. ec.europa.eu/extensions/DashboardIndicators/Biodiversity.html.

9. Environmental Protection Agency. (2018). Nitrate Directive. Retrieved February 22, 2019, from https:// eng.mst.dk/trade/agriculture/nitrates-directive/.

10. EC. (2019). The environmental objectives of the future CAP. Retrieved March 6, 2019, from https:// ec.europa.eu/info/news/environmental-care-and-climate-change-objectives-future-cap-2019-jan-25_en.

11. Eurostat (2013a). Agri-environmental indicator - soil cover. Retrieved January 9, 2019, from https:// ec.europa.eu/eurostat/statistics-explained/index.php/Agri-environmental_indicator___soil_cover. 
12. Eurostat. (2013b). Glossary: Arable land covered with cover crop or intermediate crop. Retrieved February 4, 2019, from https://ec.europa.eu/eurostat/statistics-explained/index.php/Glossary:Arable_land_covered_ with_cover_crop_or_intermediate_crop.

13. Funderburg, E. (2016). Organic matter serves important role in soil health. Retrieved February 13, 2019, from https://www.noble.org/news/publications/ag-news-and-views/2016/february/organic-matter-is-important/.

14. Function of organic matter in soil. Retrieved February 12, 2019, from http://karnet.up.wroc.pl/ weber/ rola2.htm.

15. Guo, R., Qin, W., Jiang, C., Kang, L., Nendel, C., \& Chen, Q. (2018). Sweet corn significantly increases nitrogen retention and reduces nitrogen leaching as summer catch crop in protected vegetable production systems. Soil and Tillage Research, 180, 148-153. DOI: 10.1016/j.still.2018.03.003.

16. Kaspar, T. (2009). Cover Crops for Soil and Water Quality. Retrieved February 12, 2019, from https:// www.agry.purdue.edu/cca/2009/CCA\%202009/Proceedings/Kaspar-Cover\%20Crops\%20for\%20 Soil\%20and\%20Water\%20Quality\%2010-23-09-2\%20Final\%20Version\%2011-24.pdf.

17. Molinuevo-Salces, B., Larsen, S.U., Ahring, B.K., \& Uellendahl, H. (2013). Biogas production from catch crops: Evaluation of biomass yield and methane potential of catch crops in organic crop rotations. Biomass and Bioenergy, 59, 285-292. DOI: 10.1016/j.biombioe.2013.10.008.

18. Morgan, R.P.C. (2009). Soil erosion and conservation. Blackwell Publishing.

19. Panagos, P., Borrelli, P., Meusburger, K., Alewell, C., Lugato, E., \& Montanarella, L. (2015). Estimating the soil erosion cover-management factor at the European scale. Land use policy, 48, 38-50. DOI: 10.1016/j. landusepol.2015.05.021.

20. Peltonen-Sainio, P., Rajala, A., Känkänen, H., \& Hakala, K. (2015). Improving farming systems in northern Europe. In Crop Physiology (pp. 65-91). Academic Press. DOI: 10.1016/B978-0-12-417104-6.00004-2.

21. Piotrowska-Dlugosz, A., \& Wilczewski, E. (2015). Influences of catch crop and its incorporation time on soil carbon and carbon-related enzymes. Pedosphere, 25(4), 569-579. DOI: 10.1016/S1002-0160(15)30037-0.

22. Poeplau, C., \& Don, A. (2015). Carbon sequestration in agricultural soils via cultivation of cover crops-A meta-analysis. Agriculture, Ecosystems \& Environment, 200, 33-41. DOI: 10.1016/j.agee.2014.10.024.

23. Ritter, J. (2018). Soil Erosion - Causes and Effects. Retrieved February 12, 2019, from http://www.omafra. gov.on.ca/english/engineer/facts/12-053.htm.

24. Sulima, K. (2016). Agri-environment-climate measures: support for results, controllability and the way to go? Retrieved March 7, 2019, from https://enrd.ec.europa.eu/sites/enrd/files/w12_measure10_sulima.pdf.

25. Teixeira, E.I., Johnstone, P., Chakwizira, E., de Ruiter, J., Malcolm, B., Shaw, N., ... Fraser, P. (2016). Sources of variability in the effectiveness of winter cover crops for mitigating N leaching. Agriculture, Ecosystems \& Environment, 220, 226-235. DOI: 10.1016/j.agee.2016.01.019.

26. Tosti, G., Benincasa, P., Farneselli, M., Tei, F., \& Guiducci, M. (2014). Barley-hairy vetch mixture as cover crop for green manuring and the mitigation of $\mathrm{N}$ leaching risk. European Journal of Agronomy, 54, 34-39. DOI: 10.1016/j.eja.2013.11.012.

27. Valkama, E., Lemola, R., Känkänen, H., \& Turtola, E. (2015). Meta-analysis of the effects of undersown catch crops on nitrogen leaching loss and grain yields in the Nordic countries. Agriculture, Ecosystems \& Environment, 203, 93-101. DOI: 10.1016/j.agee.2015.01.023.

28. Zinngrebe, Y., Pe’er, G., Schueler, S., Schmitt, J., Schmidt, J., \& Lakner, S. (2017). The EU's ecological focus areas - How experts explain farmers' choices in Germany. Land Use Policy, 65, 93-108. DOI: 10.1016/j. landusepol.2017.03.027. 